\title{
A Theoretical Study about Parameter Estimation of Space Distributed Local Tissue Impedance
}

\author{
Emiko Yasuno Member (Anan National College of Technology, yasuno@anan-nct.ac.jp) \\ Xueli Zhao Non-member (The University of Tokushima) \\ Yohsuke Kinouchi Member (The University of Tokushima, kinouchi@ee.tokushima-u.ac.jp) \\ Tadaoki Morimoto Non-member (The University of Tokushima)
}

\begin{abstract}
Keywords: bio-impedance, divided electrode, parameter estimation, Gauss-Newton method, EIT (Electrical Impedance Tomography)
\end{abstract}

Electrical impedance tomography (EIT) is two- or threedimensional image of electrical impedance distribution in a living tissue. Unlike usual imaging methods, i.e., X-CT, MRI and US Imaging, EIT is used for imaging the information of tissue structure and functions.

In this paper, a new configuration of the electrodes, called divided electrode, is proposed for a short time measurement of bio-impedance in a cross section of a local tissue. The cross section of the tissue is represented by space distributed equivalent circuits, and their parameters are estimated by the Gauss-Newton Method. Its capability is examined by computer simulations, where a distributed equivalent circuit is used as a model of the tissue.

Fig.1(a) shows the principle for noninvasive measurement of local tissue impedance in a cross section using divided electrodes. The divided electrode consists of many current electrodes, voltage electrodes, and guard electrodes separated each other by slits. Both sides of the current electrodes are divided into $A$ parts $\left(i_{1}, i_{2}, \cdots, i_{A}\right)$, and they are surrounded by the guard electrodes. Moreover, currents simultaneously flow from all the electrodes. Therefore, in the case of a uniform living tissue, the currents flow into the section $S$ of the center without spreading as shown in Fig.1(b), because guard currents hold down the measurement current from the both sides. Voltage electrodes are also divided into $B \operatorname{parts}\left(v_{1}, v_{2}, \cdots, v_{B}\right)$. By use of the measurement data of currents $\left(i_{1}, i_{2}, \cdots, i_{A}\right)$ and $\operatorname{voltages}\left(v_{1}, v_{2}, \cdots, v_{B}\right)$, $C(=A \times B)$ impedance data are obtained at once.

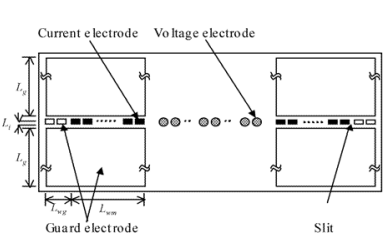

(a) Top view

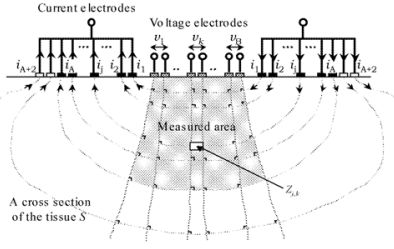

(b) Side view
Fig. 1. Divided electrode

We evaluate the effects of measurement noise and the dispersion of tissue as to the parameter estimation. We have used simple three-layer model with a tumor as shown in Fig.2. The same value has been used for the parameters for each layer. Because the living tissue is non-uniformity, the parameters are dispersed for each layer by use of the average value and the rate of standard deviation. Moreover, noise is added to calculated measurement data. It calculates that noise varies from 0 to $1.5 \%$. The number of electrodes is 25 and measurement frequency points are 20 in range of 0 to $200 \mathrm{kHz} .12$ parameters are estimated from 600 measurment data.

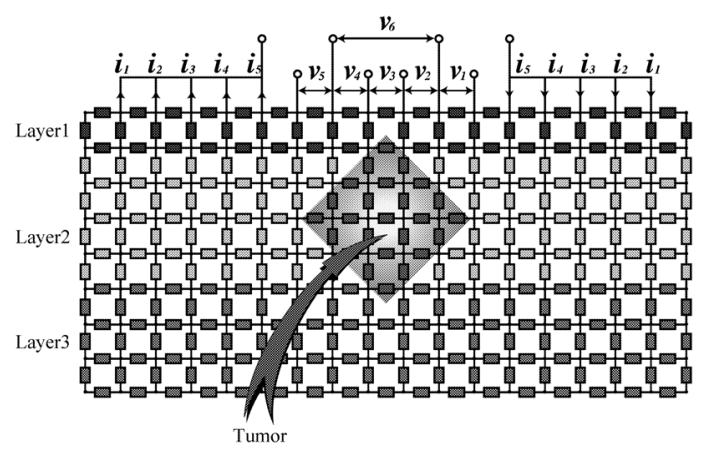

Fig. 2. Layered circuit model with a tumor

From fig.3, if the dispersion of tissue does not exist, the parameter error increase about $3.6 \%$ with noise level increase to $1.0 \%$. Similarly, if the noise level does not exist, the parameter error increase about $4.3 \%$ with dispersion of tissue increase to $1.0 \%$. Computer simulation results demonstrate that the propose method is useful for estimating the circuit parameter of a typical layered tissue model including a tumor.

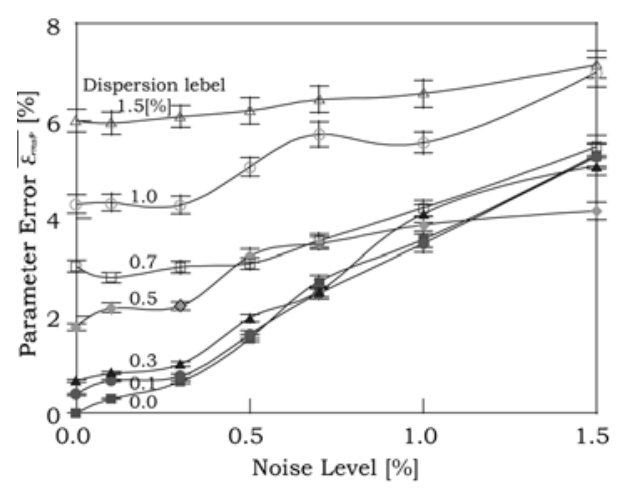

Fig. 3. Influence of noise level 


\title{
空間分布する局所組織インピーダンスの パラメータ推定に関する理論的検討
}

\author{
正 員 安野 恵実子* 非会員 趙 学麗** \\ 正員 木内 陽介** 非会員 森本 忠興***
}

\begin{abstract}
A Theoretical Study about Parameter Estimation of Space Distributed Local Tissue Impedance

Emiko Yasuno*, Member, Xueli Zhao**, Non-member, Yohsuke Kinouchi**, Member, Tadaoki Morimoto***, Non-member
\end{abstract}

In this paper, a new configuration of the electrodes, called divided electrode, is proposed for a short time measurement of bio-impedance in a cross section of a local tissue. Its capability is examined by computer simulations, where a distributed equivalent circuit is used as a model of the tissue. Estimation of impedance parameters is carried out by use of the Gauss-Newton Method. As a result of them, usefulness of the proposed method is confirmed by computer simulations using a typical layered tissue model.

キーワード : 生体インピーダンス , 分割電極 , パラメータ推定 , ガウスーニュートン法 , 電気インピーダンス・トモグラフィ Keywords: bio-impedance, divided electrode, parameter estimation, Gauss-Newton method, EIT(Electrical Impedance Tomography)

\section{1. まえがき}

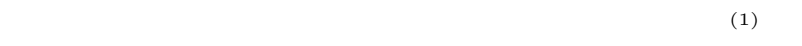
生理学的機能・状態 ${ }^{(2) \sim(4)}$ を反映しており，これを利用し た樣々な生体計測・制御に関する研究が古くから行われて いる。例えば，生体組織インピーダンスの情報は，肺呼吸 量 ${ }^{(5)}$ や血液の拍出量 ${ }^{(6)}$, 体水分・脂肪量 ${ }^{(7)}$ などのマクロ 計測に応用されている( ${ }^{(8)}$ 。

著者らの研究グループでは, 従来 3 パラメータから構成 される簡単な集中定数等価回路モデルに代わり，より正確に 生体組織インピーダンスの特性を表現する方法として，高 次集中定数等価回路モデルを用いたパラメータ推定法を提

\footnotetext{
* 阿南工業高等専門学校制御情報工学科

于 774-0017 阿南市見能林町青木 265

Department of Systems and Control Engineering, Anan National College of Technology,

Anan-shi, 774-0017

** 德島大学工学部電気電子工学科

T 770-8506 德島市南常三島町 2 丁目 1

Department of Electrical and Electronic Engineering, Faculty of Engineering, The University of Tokushima,

Tokushima-shi, $770-8506$

*** 德島大学医学部保健学科

干 770-8509 德島市蔵本町 3 丁目 18 の 5

School of Health Sciences, The University of Tokushima,

Tokushima-shi, $770-8509$
}

案した ${ }^{(9)}$ 。また , 組織の非一樣性 ,つまり，ばらつきの程度 を表現する方法として, 分布等価回路を用いて推定される 統計量から組織の非一樣性を定量的に評価した ${ }^{(10)}$ 。乥のほ か , 局所組織インピーダンスの計測方法について検討し , 臨 床的には腫瘍診断 ${ }^{(11) \sim(13)}$, 皮下組織構造・状態推定 ${ }^{(14)(15)}$ などに応用できることを明らかにした。

ところで現在，医療で行われる画像診断には，超音波検 査，X 線撮影，X 線-CT, MRI および核医学検査などが ある。周知のごとく超音波検査, $\mathrm{X}$ 線撮影および X 線-CT は質量密度分布，MRI はプロトン密度分布，核医学検査 は機能や代謝に基づく情報を画像化したものである。一方， EIT(Electrical Impedance Tomography , 以下 EIT とす る) は生体組織の電気的特性の空間分布情報を画像化したも のであり，他の画像診断装置とは異質の情報を提供するも のとして期待されている。また，測定による生体への害が なく，非侵襲で連続測定が可能であることから，臨床の場 において経時的な变化のモニタに利用できる。さらに，装 置か簡単, 安価, 小型で取り扱いが便利などの利点もある。

これまで, $\beta$ 分散周波数領域における生体組織インピー ダンスの空間分布推定に関しては, 理論的研究 ${ }^{(16) \sim(19)} も$ 進められてきているが, 臨床的に実用化されている例は少 ない。この原因は, 実際の生体のように複雑な構造をして いる場合には，生体組織インピーダンスの空間分布も複雑 であり，臨床的に必要とされる精度での測定および得られ 
た測定結果に対する情報の意味づけを明確にし難いことに あると考えられる。

生体組織インピーダンスの空間分布推定は, 測定したイ ンピーダンスデータに対して, 最小誤差で適合する等価回 路のパラメータを決定することであり，これは逆問題の一 種である。しかし，測定したインピーダンスデータと等価 回路モデルの各パラメータ値は非線形関係にあるため，解 析的に弚の関係を求めることは困難である。乥れゆえ，順 問題計算を繰り返して誤差を最小にする収束計算を行う必 要がある。さらに，生体を表す複雑な等価回路モデルの解 析は, 再構築画像の分解能を高めるために測定点を多くと らなければならなく，これまで特定部位の計測に多電極を 用いた樣々な手法力提案されている ${ }^{(20)(21)}$ 。しかしながら， 多電極を用いて測定することは実用的でないため，実用的 な電極配置や生体組織インピーダンスの分布推定，逆問題 解法アルゴリズムなどの問題解決が， EIT の実現に向けて の重要な課題となっている。

上記のことに鑑み，著者らはEIT の新しい推定法として， ガード電極を有する分割電極を用いて局所組織の 2 次元断 面における導電率分布を非侵襲計測する手法を提案し，光 の妥当性を 3 次元数值解析法に基づいて検討した ${ }^{(22)(23)}$ 。

乥こで本論文では, 生体組織が一樣であれば微小組織を 細胞内液と外液の特性を分離して捉えることができる等価 回路表現に着目し，局所組織の 2 次元断面を等価回路モデ ルで置き換えている。光して, 弚の回路パラメータの推定 方法を提案することを目的としている。パラメータの推定 方法にはガウス-ニュートン法を適用し，兴の有用性は，生 体組織をモデル化した複数の簡単な等価回路モデルに対す る計算機シミュレーションにより検証している。

\section{2. 測定方法}

測定電極は，図 1(a) に示すような平板電極 (電流電極と

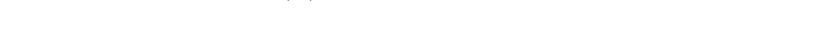
た分割電極を想定している。電流電極はガード電極で挟ま れた $A+2$ 個に分割された測定電極 $i_{1} \sim i_{A+2}$ と，ガード 電極で挟み込むように構成される。一方，電圧電極も $B+1$ 個に分割され，弚の電圧を $v_{1} \sim v_{B}$ とする。電流電極間に $v_{a}$ を加え, 印加電流 $i_{1} \sim i_{A+2}$, 応答電圧 $v_{1} \sim v_{B}$ を測定 する。このとき $v_{a}$ はパルスでも周波数を変化させた正弦 波電圧でもよい。

著者らの以前の論文では, 図 $1(\mathrm{~b})$ において $L_{w m}$ を $2.0 \mathrm{~cm}$ とした場合，電流電極幅 $L_{i}$ とガード電極幅 $L_{g}$ の関係が $L_{g}>50 L_{i}$ であれば，電流の約 $90 \%$ は電極の真下を流れ， 光れ以外は 3 次元的に分布することを数値解析により確認 している ${ }^{(22) 。 も ち ろ ん ， ~} L_{w m}$ を大きくすれば電極の真下 を流れる電流は $90 \%$ 以下となり 3 次元的分布を示すが , こ こでは電流分布が 2 次元分布とみなすことができる電極幅 $L_{w m}$ を想定している。したがって，組織が一樣であると仮 定すると，中央の断面 $S$ における電流流線は，図 1(c) の ように, 電流 $i_{1} \sim i_{A}$ の経路は内側方向となるのに対して，

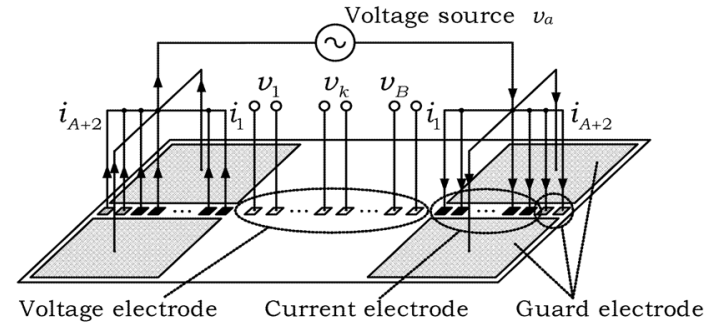

(a) Top view

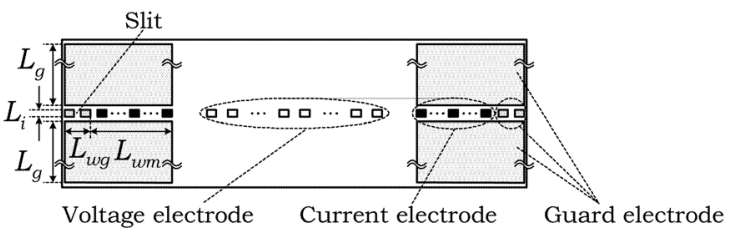

(b) Bottom view

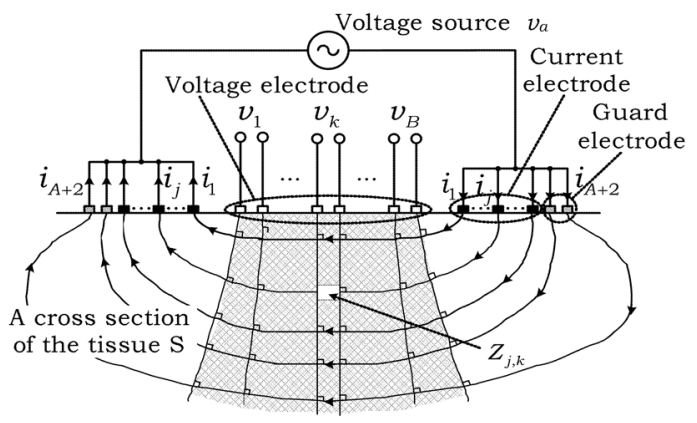

(c) Side view

图 1 分割電極

Fig. 1. Divided electrode.

$i_{A+1}, i_{A+2}$ は先ず外側方向に向かったのち内側方向に向か う大きな長い経路となる。したがって， $i_{A+1}, i_{A+2}$ はガー ド電極と見なし，パラメータ推定に利用する測定インピー ダンスを求める際には $i_{1} \sim i_{A}$ と $v_{1} \sim v_{B}$ を用いる。例え ば， $i_{j}, v_{k}$ ぞれぞれのフーリ工変換を $I_{j}, V_{k}$ で表すと，パ ラメータ推定に利用する測定インピーダンス $Z_{j, k}$ は，

$$
Z_{j, k}=\frac{V_{k}}{I_{j}} \quad(j=1, \cdots, A, k=1, \cdots, B) \cdots
$$

により求まり，これは図 $1(\mathrm{c})$ に示す電流流線 $j$ と等電位線 $k$ との交点付近を測定していることになる。ただし，実際の 位置は組織の特性や厚さ, 周波数によって異なるため, 特 定は困難である。光こで，本論文て提案するインピーダン ス推定法は，予め超音波画像診断装置などで測定領域下の 組織の特性や厚さ，腫瘍の位置を把握できることを前提と し，关の結果を考慮した分布等価回路を用いて，腫瘍の位 置推定ではなくインピーダンスの空間分布を推定すること を目的としていることに注意する。

分割電極は 1 回の測定で $A$ 個の印加電流と $B$ 個の応答電 圧を測定することにより， $C(=A \times B)$ 個の測定インピー ダンスを計算から得られる。これは，従来 EIT の測定で用 いられてきた電極を切り替えて電流を印加する多電極法と 比較すると，測定時間の短縮となる。また，電流電極数と 電圧電極数を増やせば，深さ方向と電極軸方向光れ攵れへ 
測定領域が広がる。さらに，スリット数を増やせば，測定領 域内のデー夕数も増えるため, 空間分解能が向上する。こ のように単なる四電極法 ${ }^{(24)}$ とは異なり，電流と電圧電極 の組み合わせによって断面状の特定の組織要素を容易に測 定できることから，空間分解能を上げた 2 次元分布が得ら れる。乥れゆえ，本論文で扱う測定方法としては，图 1(b) の分割電極を図 1(c) のように生体の皮膚表面に電極を取り 付け , 非侵襲計測を行うことを想定している。

\section{3. 等価回路のパラメータ推定}

〈3.1〉等価回路モデル 害際の組織は機能的に同一で あっても, 細胞の密度 , 形状 , 大きさ, 位置などにより空間 的な非一栐性が存在する。通常，二の非一樣性は, 細胞外液 抵抗や細胞内液抵抗, 形質膜容量に由来する高次集中定数 等価回路 ${ }^{(9)}$ で表現するものと，3 パラメータ等価回路の電 気的緩和時間 (等価回路の時定数) が Cole_Cole 分布 ${ }^{(25)} や$ Davidson-Cole 分布 ${ }^{(26)(27)}$ であるとして取り扱うものがあ る。前者は組織構造との対応が可能であり，なかでも 3 パ ラメータ等価回路は 1 つの緩和時間しか持っておらず，し かも組織レベルで生体を等価回路表現したものであるため， 個人差のある皮下脂肪組織厚や組織の非一樣性は反映され ない。一方，後者の Cole_Cole 円弧則や Davidson-Cole 円 弧則は, $\beta$ 分散領域のインピーダンスを表現するのに適し ているが, 組織の平均的な特性だけを表すため, 異なる組 織の特性を分離して表現することは困難である。

弚こで本論文では，生体を微小組織で分割し，光の微小 組織は一樣であると想定して 3 パラメータ等価回路で表現 する。乥の等価回路は細胞外液抵抗 $R_{e}$, 細胞内液抵抗 $R_{i}$, 形質膜容量 $C_{m}$ をパラメータにもつ 3 パラメータ等価回路 として表すことができる。微小組織が多数集まって生体を 構成していると考えると, 図 1 に示す分割電極で測定した 組織の断面は 2 次元空間分布等価回路で表現できる ${ }^{(28)}(29) 。$ ここで, 代表的な正方格子回路モデルを参考に，図 2 に示 す等価回路モデルを用いる。ただし，電極は点電極と考え ている。このような格子状の等価回路では，電極の位置は 電極を接続する接点の位置を変えることにより自由に変更 できるため，あらゆる測定電極に対応できる。

〈3. 2〉パラメー夕推定方法 前述のように電流電極 $A+2$ 個，電圧電極 $B+1$ 個から構成される分割電極を用 いると $C$ 個のインピーダンスが測定される。さらに , 測定 周波数 $\omega_{j}(j=1 \sim U)$ で測定する場合について，各パラ メータの推定方法を述べる。インピーダンスの測定として は，振幅と位相を持つ測定インピーダンス $\mathbf{Z}_{\mathrm{D} 1}$ ，測定を簡 単にするため振幅のみの測定インピーダンス $\mathbf{Z}_{\mathrm{D} 2}$ を考え， これらを

$$
\begin{aligned}
\mathbf{Z}_{\mathrm{D} 1}= & {\left[Z_{D}{ }^{(1)}\left(\omega_{1}\right), \cdots, Z_{D}{ }^{(1)}\left(\omega_{U}\right),\right.} \\
& \left.Z_{D}{ }^{(2)}\left(\omega_{1}\right), \cdots, Z_{D}{ }^{(C)}\left(\omega_{U}\right)\right]^{T}
\end{aligned}
$$

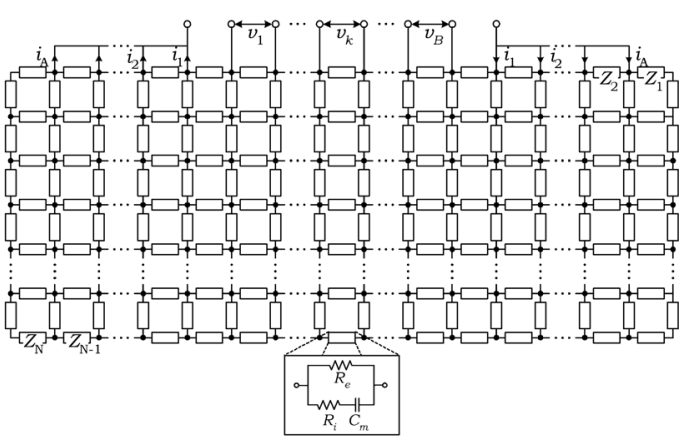

図 22 次元分布等価回路モデル

Fig. 2. Two dimensional distributed equivalent circuit model.

$$
\begin{aligned}
\mathbf{Z}_{\mathrm{D} 2}= & {\left[\left|Z_{D}^{(1)}\left(\omega_{1}\right)\right|, \cdots,\left|Z_{D}^{(1)}\left(\omega_{U}\right)\right|,\right.} \\
& \left.\left|Z_{D}^{(2)}\left(\omega_{1}\right)\right|, \cdots,\left|Z_{D}^{(C)}\left(\omega_{U}\right)\right|\right]^{T} \cdots \cdots
\end{aligned}
$$

で表す。一方, 分割電極を用いて測定される領域を, 図 2 に示す 2 次元分布等価回路モデルで, 各回路素子は 3 パラ メータ等価回路で表し，兴れが $N$ 個接続されたものについ て考えると，パラメータベクトル $\mathrm{p}$ は，

$$
\begin{aligned}
\mathbf{p}= & {\left[R_{e}(1), R_{i}(1), C_{m}(1), \cdots\right.} \\
& \left.\cdots, R_{e}(N), R_{i}(N), C_{m}(N)\right]^{T}
\end{aligned}
$$

と定義できる。ここで $T$ は行列の転置を示す。振幅と位相 をもつ回路モデルインピーダンス $\mathbf{Z}_{\mathrm{M} 1}(\mathbf{p})$ と，振幅のみの 回路モデルインピーダンス $\mathbf{Z}_{\mathrm{M} 2}(\mathbf{p})$ は，

$$
\begin{aligned}
\mathbf{Z}_{\mathrm{M} 1}(\mathbf{p})= & {\left[Z_{M}^{(1)}\left(\mathbf{p}, \omega_{1}\right), \cdots, Z_{M}^{(1)}\left(\mathbf{p}, \omega_{U}\right),\right.} \\
& \left.Z_{M}^{(2)}\left(\mathbf{p}, \omega_{1}\right), \cdots, Z_{M}^{(C)}\left(\mathbf{p}, \omega_{U}\right)\right]^{T} \cdots \\
\mathbf{Z}_{\mathrm{M} 2}(\mathbf{p})= & {\left[\left|Z_{M}^{(1)}\left(\mathbf{p}, \omega_{1}\right)\right|, \cdots,\left|Z_{M}^{(1)}\left(\mathbf{p}, \omega_{U}\right)\right|,\right.} \\
& \left.\left|Z_{M}^{(2)}\left(\mathbf{p}, \omega_{1}\right)\right|, \cdots, \mid Z_{M}^{(C)}\left(\mathbf{p}, \omega_{U} \mid\right)\right]^{T}
\end{aligned}
$$

で表される。

ここで, パラメータベクトル $\mathrm{p}$ を与えた回路モデルイ ンピーダンス $\mathbf{Z}_{\mathrm{M} 1}(\mathbf{p}), \mathbf{Z}_{\mathrm{M} 2}(\mathbf{p})$ と，测定インピーダンス $\mathbf{Z}_{\mathrm{D} 1}, \mathbf{Z}_{\mathrm{D} 2}$ との差を弚れ光れ $\varepsilon_{1}(\mathbf{p}) ， \varepsilon_{2}(\mathbf{p})$ で定義すると，

$$
\begin{aligned}
& \varepsilon_{1}(\mathbf{p})=\mathbf{Z}_{\mathrm{M} 1}(\mathbf{p})-\mathbf{Z}_{\mathrm{D} 1} \\
& \varepsilon_{2}(\mathbf{p})=\mathbf{Z}_{\mathrm{M} 2}(\mathbf{p})-\mathbf{Z}_{\mathrm{D} 2}
\end{aligned}
$$

で与えられる。回路モデルインピーダンスの各パラメータ 值を推定するためには，

$$
\varepsilon_{j}(\mathbf{p})=\mathbf{0} \quad(j=1,2) \cdots \cdots
$$

となるパラメータベクトル $\mathrm{p}$ を求める逆問題を解く必要 がある。しかしながら, 回路モデルの各パラメータ值と測 定インピーダンスの関係は非線形であるため，解析的に解 
くことは困難である。しかし，測定対象の生体組織の大凡 の值は実測値より既知であるため，弚れらを初期值とすれ ばニュートン法を適用した数值解析が有用であると考えら れる。

$t$ 番目のパラメータベクトル $\mathbf{p}^{(t)}$ から $t+1$ 番目を求め るには以下の式を用いる。

$$
\begin{gathered}
-\frac{\partial \varepsilon_{1}\left(\mathbf{p}^{(t)}\right)}{\partial \mathbf{p}} \delta \mathbf{p}^{(t)}=\varepsilon_{1}\left(\mathbf{p}^{(t)}\right) \\
-\frac{\partial \varepsilon_{2}\left(\mathbf{p}^{(t)}\right)}{\partial \mathbf{p}} \delta \mathbf{p}^{(t)}=\varepsilon_{2}\left(\mathbf{p}^{(t)}\right)
\end{gathered}
$$

となる。したがって， $\mathbf{p}^{(t+1)}=\mathbf{p}^{(t)}+\delta \mathbf{p}^{(t)}$ により求まる。

$U$ 次元複素べクトルを $\mathbf{Y}_{1}, U$ 次元実数べクトルを $\mathbf{Y}_{2}$ ， $(U \cdot C \times 3 N)$ 複素行列を $\mathbf{X}_{1},(U \cdot C \times 3 N)$ 実数行列を $\mathbf{X}_{2}$ とすると，式 (10),(11) は，

$$
\begin{aligned}
& \mathbf{X}_{1} \delta \mathbf{p}_{1}=\mathbf{Y}_{1} \\
& \mathbf{X}_{2} \delta \mathbf{p}_{2}=\mathbf{Y}_{2}
\end{aligned}
$$

とまとめられる。ここで，

$$
\begin{aligned}
& \mathbf{X}_{1}=\left[\frac{\partial \varepsilon_{1}\left(\mathbf{p}^{(\mathrm{t})}, \omega_{1}\right)}{\partial \mathbf{p}}, \cdots, \frac{\partial \varepsilon_{1}\left(\mathbf{p}^{(\mathrm{t})}, \omega_{U}\right)}{\partial \mathbf{p}}\right]^{T} \\
& \mathbf{X}_{2}=\left[\frac{\partial \varepsilon_{2}\left(\mathbf{p}^{(\mathrm{t})}, \omega_{1}\right)}{\partial \mathbf{p}}, \cdots, \frac{\partial \varepsilon_{2}\left(\mathbf{p}^{(\mathrm{t})}, \omega_{U}\right)}{\partial \mathbf{p}}\right]^{T} \\
& \text {.................. } \\
& \mathbf{Y}_{1}=\left[\varepsilon_{1}\left(\mathbf{p}^{(\mathrm{t})}, \omega_{\mathbf{1}}\right)^{T}, \cdots, \varepsilon_{1}\left(\mathbf{p}^{(\mathrm{t})}, \omega_{\mathbf{U}}\right)^{T}\right]^{T} \\
& \mathbf{Y}_{2}=\left[\varepsilon_{2}\left(\mathbf{p}^{(\mathrm{t})}, \omega_{\mathbf{1}}\right)^{T}, \cdots, \varepsilon_{2}\left(\mathbf{p}^{(\mathrm{t})}, \omega_{\mathbf{U}}\right)^{T}\right]^{T}
\end{aligned}
$$

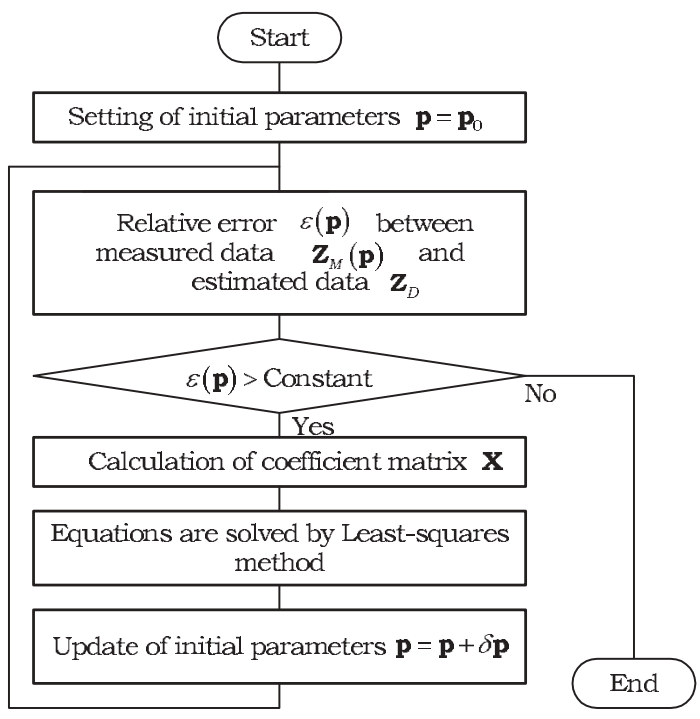

図 3 フローチャート

Fig. 3. Flowchart.
である。測定データを未知パラメータより多く(一般に $U \cdot C>3 N)$ とっておき，式 (12),(13) を最小二乗法で 解き, 各パラメータの変化量 $\delta \mathbf{p}_{1}, \delta \mathbf{p}_{2}$ は次式より求まる。

$$
\begin{array}{r}
\delta \mathbf{p}_{1}=\left(\mathbf{X}_{1}^{T} \overline{\mathbf{X}_{1}}+\overline{\mathbf{X}_{1}{ }^{T}} \mathbf{X}_{1}\right)^{-1}\left(\mathbf{X}_{1}{ }^{T} \overline{\mathbf{Y}_{1}}+\overline{\mathbf{X}_{1}{ }^{T}} \mathbf{Y}_{1}\right) \\
\ldots \ldots \ldots \ldots \ldots \ldots \cdot(18) \\
\delta \mathbf{p}_{2}=\left(\mathbf{X}_{2}{ }^{T} \mathbf{X}_{2}\right)^{-1}\left(\mathbf{X}_{2}^{T} \mathbf{Y}_{2}\right) \ldots \ldots \ldots \cdot(19)
\end{array}
$$

ここで， $\overline{\mathbf{X}_{1}} ， \overline{\mathbf{X}_{2}}$ は $\mathbf{X}_{1} ， \mathbf{X}_{2}$ のユニタリ行列である。図 3 にこのアルゴリズムのフローチャートを示す。

\section{4. 推 定 例}

本推定法の有用性を示すために, 計算機シミュレーション により 2 次元分布等価回路モデルのパラメータ推定を行っ た。2 次元分布等価回路としては種々の回路モデルが考えら れるが, 簡単な層状構造モデルについてのシミュレーショ ン結果を次に示す。尚，層状構造モデルは電極軸方向の組 織は一樣であると考え，図 1(b) に示した測定電極の左右両 端中央部に位置するガード電極は考慮していない。

〈4:1〉層状構造モデル 図 4 に示すように, 回路網 の接点数に対して要素数が多い三角格子回路モデルについ て検討した。これは正方格子モデルに比べて要素密度が高 く，空間をより正確に表現できる。本電極は局所組織を測 定対象としており，弚の代表例として本論文では乳房をモ デル化している。実際の組織は, 皮膚, 脂肪, 乳腺, 筋肉と あるが相対的に考えると皮膚は薄いので, 脂肪, 乳腺, 筋 肉から構成された層状構造モデルについて考える。回路モ デルを作成するにあたり，各層の境界は超音波診断装置な どて既知であるとし，回路素子数は 300 個としているが， 同一層内では各パラメータ值も同じとしており，未知パラ メータは 9 個となる。電流電極 5 個，電圧電極 6 個の分割 電極を用い, 測定周波数 $0,1,3,5,10,20,30,50,70,100 \mathrm{kHz} の$ 10 点で測定したインピーダンスデータを用い, 各パラメー タの推定を行った。モデルの各パラメータ值 $\left(R_{e}, R_{i}, C_{m}\right)$ は実際に各組織を針電極により測定した值から設定したも ので，初期パラメータ值は表 1 に示す適当な值である。行 列 X を数值解析により計算し, 本推定法を用いた結果を表 2 に，弚のときの誤差曲線を図 5 に示す。初期パラメータ を標準モデルの各パラメータ値 (真値) から $20 \%$ 程度離れ

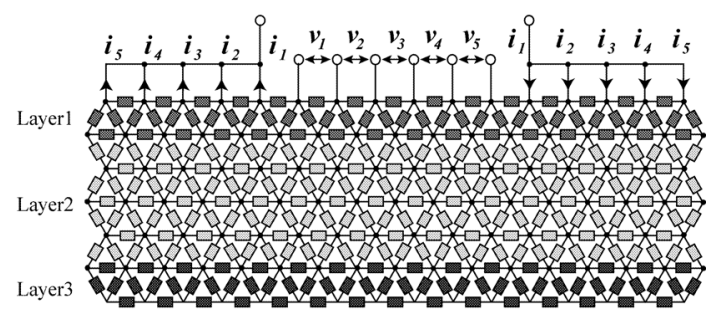

図 4 層状構造回路モデル

Fig. 4. Layered circuit model. 
表 1 標準モデルと初期値の各パラメータ值 1

Table 1. Parameter value of the model and initial values \#1.

\begin{tabular}{|l||c|c|c|c|c|c|}
\hline \multicolumn{1}{|c||}{} & \multicolumn{3}{c|}{ Model parameters $\mathrm{p}$} & \multicolumn{3}{c|}{ Initial parameters $\mathrm{p}_{0}$} \\
\cline { 2 - 7 } & $R_{e}[\Omega]$ & $R_{i}[\Omega]$ & $C_{m}[n \mathrm{~F}]$ & $R_{e}[\Omega]$ & $R_{i}[\Omega]$ & $C_{m}[n \mathrm{~F}]$ \\
\hline \hline Layer1 & 250 & 250 & 6 & 200 & 200 & 7 \\
Layer2 & 50 & 50 & 44 & 100 & 100 & 40 \\
Layer3 & 83 & 83 & 16 & 100 & 100 & 20 \\
\hline
\end{tabular}

表 2 推定パラメータ值 1

Table 2. Estimated parameters \#1.

\begin{tabular}{|l||c|c|c|}
\hline & $R_{e}[\Omega]$ & $R_{i}[\Omega]$ & $C_{m}[n \mathrm{~F}]$ \\
\hline \hline Layer1 & 250.0 & 250.0 & 6.0 \\
Layer2 & 50.0 & 50.0 & 44.0 \\
Layer3 & 83.0 & 82.9 & 15.9 \\
\hline
\end{tabular}

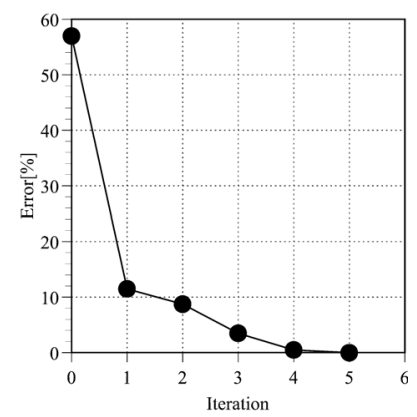

図 5 推定結果 1 (誤差曲線)

Fig. 5. Estimated result \#1(Error curve).

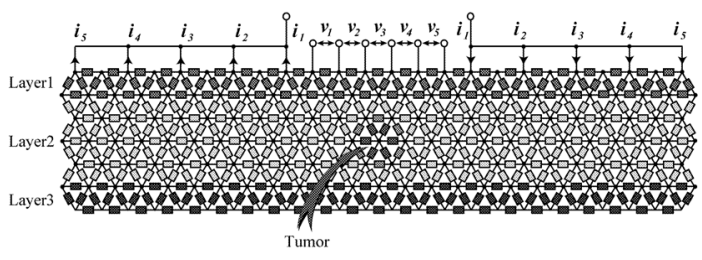

図 6 腫瘍のある層状構造回路モデル

Fig. 6. Layered circuit model with a tumor.

た值に設定しても，真值を推定することができた。

推定結果より，電流電極から流れ込む電流は図 1(c) の $Z_{j, k}$ を流れたと考えられ，各層の情報を分離して得ること ができた。

〈4. 2〉 腫瘍のある層状構造回路モデル 本研究の最 終目的の 1 つが腫瘍の位置推定ではなくインピーダンス值 の推定にあるため，ここでは図 6 に示すように，前節で示 した層状構造回路モデルをさらに複雑にし， 2 層目の中央 部に腫瘍のある場合について検討した。腫瘍を表す回路モ デルが 2 層構造になっているのは, 実際の腫瘍が , 外部よ り中心部の抵抗值が高いという特徵を考慮している。この モデルは 15 個のパラメータをもち, 回路素子数 452 個, 前 節で用いた測定周波数で測定したインピーダンスデータを
表 3 標準モデルと初期值の各パラメータ值 2

Table 3. Parameter value of the model and initial values \#2.

\begin{tabular}{|c||c|c|c|c|c|c|}
\hline \multicolumn{1}{|c||}{} & \multicolumn{3}{c|}{ Model parameters $\mathrm{p}$} & \multicolumn{3}{c|}{ Initial parameters $\mathrm{p}_{0}$} \\
\cline { 2 - 7 } & $R_{e}[\Omega]$ & $R_{i}[\Omega]$ & $C_{m}[n \mathrm{~F}]$ & $R_{e}[\Omega]$ & $R_{i}[\Omega]$ & $C_{m}[n \mathrm{~F}]$ \\
\hline \hline Layer1 & 250 & 250 & 6 & 200 & 200 & 7 \\
Layer2 & 30 & 30 & 44 & 50 & 50 & 27 \\
Layer3 & 83 & 83 & 16 & 80 & 80 & 17 \\
Tumor1 & 63 & 63 & 21 & 60 & 60 & 22 \\
Tumor2 & 57 & 57 & 23 & 60 & 60 & 22 \\
\hline
\end{tabular}

表 4 推定パラメータ值 2

Table 4. Estimated parameters \#2.

\begin{tabular}{|c||c|c|c|}
\hline & $R_{e}[\Omega]$ & $R_{i}[\Omega]$ & $C_{m}[n \mathrm{~F}]$ \\
\hline \hline Layer1 & 250.0 & 250.1 & 6.0 \\
Layer2 & 30.0 & 29.9 & 44.0 \\
Layer3 & 83.0 & 84.1 & 16.1 \\
Tumor1 & 63.0 & 62.3 & 20.9 \\
Tumor2 & 57.0 & 57.6 & 23.1 \\
\hline
\end{tabular}

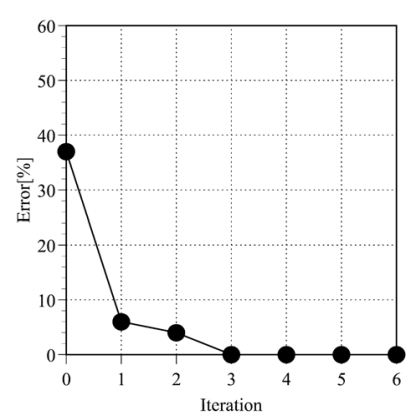

図 7 推定結果 2 (誤差曲線)

Fig. 7. Estimated result \#2(Error curve).

使い , 各パラメータの推定を行った。標準モデルの各パラ メータ值 (真值) は表 3 とする。

腫瘍のない場合とある場合でシミュレーションを行った が, 共に初期パラメータをモデルの各パラメータ值から大 きく離れた值に設定しても，真值に近い值に推定できた。 ただし, 標準モデルの各パラメータと初期パラメータの誤 差をさらに大きく設定すると局所解に陥つてしまい, パラ メータの推定ができなかった。

\section{5. 組織の非一様性と雑音の影響}

実際の測定データには, 生体組織の持つ非一樣性や測定時 の雑音が含まれている。ここでは,これらか推定精度に及ぼ す影響について検討する。回路モデルは図 8 に示すように， 2 層目に腫瘍のある 3 層構造モデルであり，4つの組織で 構成されている。電流電極 5 個, 電圧電極 6 個と, 測定 周波数 $0,1,2,3,4,5,7,8,10,15,20,30,40,50,70,100,120,150$, $170,200 \mathrm{kHz}$ までの 20 点で測定したデータを使い， 600 個 の測定データから 12 個のパラメータ推定を行った。図 8 に示す回路モデルの各ブロック内には, 細胞数が十分あり， 


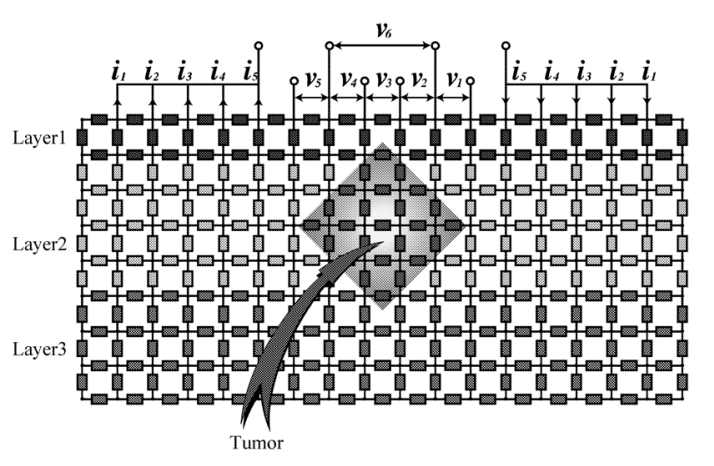

図 8 腫瘍のある層状構造回路モデル 2

Fig. 8. Layered circuit model with a tumor \#2.

表 5 モデルのパラメータの平均と標準偏差

Table 5. The standard deviation and the average value of the sample value.

\begin{tabular}{|c||c|c|c|c|c|c|}
\hline \multicolumn{1}{|c||}{} & \multicolumn{3}{c|}{ Average parameters } & \multicolumn{3}{c|}{ Standard deviation } \\
\cline { 2 - 7 } & $R_{e}[\Omega]$ & $R_{i}[\Omega]$ & $C_{m}[\mathrm{nF}]$ & $R_{e}[\Omega]$ & $R_{i}[\Omega]$ & $C_{m}[\mathrm{nF}]$ \\
\hline \hline Layer1 & 250.33 & 249.97 & 6.00 & 2.83 & 2.89 & 0.07 \\
Layer2 & 50.08 & 50.01 & 33.96 & 0.50 & 0.45 & 0.45 \\
Layer3 & 83.03 & 82.96 & 15.99 & 0.80 & 0.79 & 0.16 \\
Tumor & 109.78 & 110.05 & 10.98 & 1.35 & 0.95 & 0.08 \\
\hline
\end{tabular}

弚れらの平均値を各パラメータ值としているため, 同一組 織なら光のばらつきは小さいと思われる。光れゆえ，生体 組織の持つ非一樣性は各組織のパラメータ值を平均值とし， $0.1 \sim 1.5 \%$ となる標準偏差を用いて各パラメータをばらつ かせた (表 5$)$ 。また , 測定時の雑音は, 非一樣性のあるモ デルを基に計算した測定データに光れどれ正規乱数を加え $0.1 \sim 1.5 \%$ の雑音とした。このデータを基に適当な初期値 からガウスーニュートン法を適用しパラメータ推定を行った。

推定結果の一例として , 式 (20) で表すパラメータの rms 誤差と雑音レベルの変化および組織のばらつきの関係につ

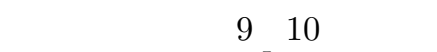

$$
\overline{\varepsilon_{r m s P}}=\frac{1}{L} \sum_{j=1}^{L} \varepsilon_{r m s P(j)} \quad(j=0 \sim 3) \cdots
$$

ただし， $L$ は組織数である。このとき，

$$
\begin{aligned}
\varepsilon_{r m s P(j)} & =\sqrt{\frac{\left(\varepsilon_{R_{e}}^{(j)}\right)^{2}+\left(\varepsilon_{R_{i}}^{(j)}\right)^{2}+\left(\varepsilon_{C_{m}}^{(j)}\right)^{2}}{3}} \ldots \ldots \\
\varepsilon_{R_{e}}^{(j)} & =\frac{R_{e D}^{(j)}-R_{e M}^{(j)}}{R_{e D}^{(j)}} \ldots \ldots \ldots \ldots \ldots \ldots \ldots \ldots \\
\varepsilon_{R_{i}}^{(j)} & =\frac{R_{i D}^{(j)}-R_{i M}^{(j)}}{R_{i D}^{(j)}} \ldots \ldots \ldots \ldots \ldots \ldots \\
\varepsilon_{C_{m}}^{(j)} & =\frac{C_{m D}^{(j)}-C_{m M}^{(j)}}{C_{m D}^{(j)}} \ldots \ldots \ldots \ldots \ldots
\end{aligned}
$$

である。ここで, $R_{e D}, R_{i D}, C_{m D}$ は光れ光れ測定インピー ダンスから推定した回路パラメータ, $R_{e M}, R_{i M}, C_{m M}$ は

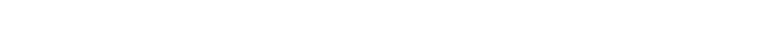

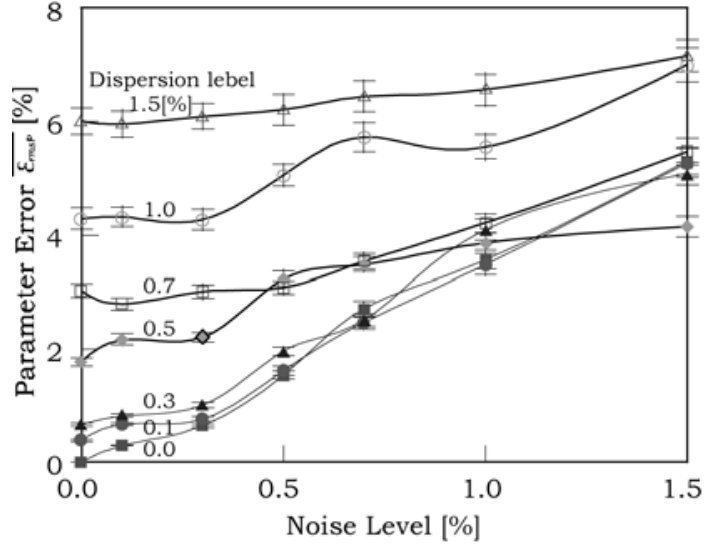

図 9 雑音に対するパラメータの rms 誤差

Fig. 9. Influence of noise level.

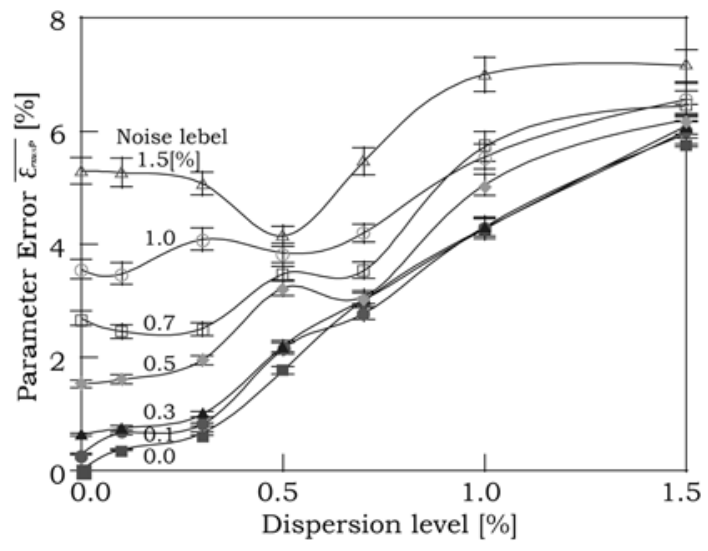

図 10 組織のばらつきに対するパラメータの rms 誤差

Fig. 10. Influence of dispersion level of tissue.

図 9 より,組織のばらつきがない場合，雑音レベルが $0 \%$ から $1 \%$ に増加すれば，約 $3.6 \%$ の rms 誤差の増加が確 認できた。また，組織のばらつきがある場合は，組織のば らつきが大きいほど雑音レベルの影響は $\mathrm{rms}$ 誤差に表れに くい。同樣に, 図 10 より, 杂隹音がない場合, 組織のばらつ きが $0 \%$ から $1 \%$ に増加すれば，約 $4.3 \%$ の rms 誤差の増加 が確認できた。また，雑音レベルがある場合は，雑音レべ ルが大きいほど組織のばらつきの影響は $\mathrm{rms}$ 誤差に表れに くい。

\section{6. むすび}

本論文では, EIT の新しい推定法として, ガード電極を 有する分割電極を用いて，局所組織の 2 次元断面を等価回 路モデルで置き換え, 光の回路パラメータの推定方法を提 案した。また，生体組織をモデル化した複数の簡単な回路 モデルに対し，ガウスーニュートン法を用いたパラメータ 推定アルゴリズムを適用し，シミュレーション解析により 兴の有用性を検証した。乥の結果, 本手法は局所組織イン 
ピーダンスのパラメータ推定が可能であることが確認され た。また , パラメータ推定に影響があると考えられる雑音 と組織の非一樣性について検討した結果，雑音レベルが大 きいと組織のばらつきによる影響はほとんど見られないこ とが確認された。

以上の解析結果より，ガード電極を有する分割電極は，組 織の非一樣性を定量的に評価できる局所組織インピーダン スの空間分布推定に適した測定電極であると考えられ，局 所組織の代表例として表在性腫瘍の診断, 牛や豚の肉質検 査などへの応用が期待される。

\section{謝 辞}

本研究に対してご助言を頂いた, 徳島大学工学部電気電 子工学科入谷忠光教授，およひ協力して頂いた德島大学大 学院工学研究科院生丹治佑介氏ならびに駒井佑美氏に深く 感謝いたします。

なお, 本研究の一部は科学研究費補助金 (若手研究 (B)16700374, 萌芽研究 16650111) の援助を受けて行わ れたものである。

(平成 16 年 11 月 8 日受付)

\section{文献}

（1）金井 寛：「生体物性 (2) - 電気特性」, ME 誌, Vol.13, No.5, pp.49-57 (1975)

( 2 ) L.A. Geddes and H.E. Hoff: "The measurement of physiologic events by electrical impedance", a review, Am. J. Med. Electr., pp. 16-27 (1964)

(3) H. Kunii and Y. Kinouchi: "A Study of Electrical BioImpedance Over Time in Extracted Rat Livers", JJME, Vol.31, No.3, pp.233-238 (1993-9) (in Japanese) 小西康備・森本忠興・木内陽介・入谷忠光・門田康正 :「摘出ラッ卜 肝の電気インピーダンスの経時的変化に関する研究」, $\mathrm{ME}$ 誌, $\mathbf{3 1}$, 3, pp.233-238 (1993-9)

(4) Y. Kinouchi, T. Iritani, T. Morimoto, and S. Ohyama: "Fast in vivo measurements of local tissue impedances using needle electrodes", Medical \& Biological Engineering \& Computing, pp.486-492 (1997)

(5) L.E. Baker: "Applications of the impedance technique to the respiratory system", IEEE Eng. Med. \& Biol. Mag., 8, pp.50-52 (1989)

(6) R.P. Patterson: "Fundamentals of impedance cardiography", IEEE Eng. Med. \& Biol. Mag., 8, pp.35-38 (1989)

( 7 ) K. Sakamoto, K. Kaneko, M. Ezaki, et al.: "Estimation of human wholes body fat volume by electrical impedance method", Jpn. J. Med. Electro. Biol. Eng., 33, pp.2-9 (1995)

（8）金井 寛：「生体電気インピーダンスと关の臨床応用」, ME 誌, Vol.20, No.3, pp.140-146 (1982-06)

(9) H. Kunii and Y. Kinouchi: "Parameter Estimation of Lumped Element Equivalent Circuits For Tissue Impedance", IEICE Japan, Vol.J82-DII, No.11, pp.2143-2151 (1999-11) (in Japanese)

國井洋臣・木内陽介：「生体組織インピーダンスの集中定数等価回 路とパラメータ推定」, 信学論 D , J82-DII , 11，pp.2143-2151 (1999-11)

(10) H. Okabe, E. Fujimoto, and Y. Kinouchi: "Equivqlent Distributed Circuits for Bioimpedance of Nonuniform Tissue and their Characteristics", IEICE Japan, Vol.J80-DII, No.7, pp.1947-1954 (1997-7) (in Japanese) 岡部 洋・藤本恵実子・木内陽介：「組織の非一樣性を考慮した生体 インピーダンスの等価分布回路と光の特性」, 信学論 D , J80-DII， 7 , pp.1947-1954 (1997-7)

(11) T. Morimoto, Y. Kinouchi, T. Iritani, et al.: "Measurement of the Electrical Bio-impedance of Breast Tumors", European
Surgical Research, Vol.22, pp.86-92 (1990)

(12) T. Morimoto, S. Kimura, Y. Konishi, K.Komaki, T. Uyama,Y.Monden, Y. Kinouchi, and T.Iritani: "A study of the electrical bioimpedance of tumors", J. Invest. Surg., 6, pp.25-32 (1993)

(13) Y. Konishi, T.morimoto. Y. Kinouchi, T. Iritani, and Y. Monden: "Electrical Properties of Extracted Rat Liver Tissue", Research in Experimental Medicine, Vol.195, pp.183$192(1995)$

(14) N. Momose, Y. Kinouchi, T. Iritani, T. Morimoto, and H. Okabe.: "Three dimensional analysis of local tissue impedance by a finite element method", World Congress on Medical Physics and Biomedical Engineering, pp.347 (1997)

(15) A. Ihara, T. Morimoto, X. Zhao, Y. Kinouchi, T. Iritani, and Y. Oomine: "Finite Element Analysis of Breast Bioimpedance", Proc. of The 4th Asia-Pacific Conference on Medical and Biological Engineering, p.452 (1999)

(16) Y. Yamashita et al.: "Method and feasibility of estimating impedance distribution in the human torso", Proc. 5th ICEBI, p.87 (1981)

(17) K. Nakayama et al.: "Fundamental study on electrical CT algorithm utilizing sensitivity theorem on impedance plethysmography", Proc. 5th ICEBI, pp.99 (1981)

(18) Y. Yamamoto and T. Yamamoto: "Measurement of electrical bioimpedance and its applications", Medical Progress through Technology, 12, pp.171-183 (1987)

(19) J.J. Ackmann and M.A. Seitz: "Methods of complex impedance measurements in biologic tissue", Crit. Rev. Biomed. Eng., 11, pp.281-311 (1984)

(20) K. Sakamoto: "Special issue:New computed tomography. Impedance computed tomography", BME, Vol.8, No.8, pp.4956 (1994-8) (in Japanese)

酒本勝之 :「特集 : 新しい $\mathrm{CT}$ インピーダンス $\mathrm{CT}\lrcorner, \mathrm{ME}$ 誌, 8 , 8, pp.49-56 (1994-8)

(21) N. Chauveau, B. Ayeva, B. Rigaud, and J.P. Morucci: "A multifrequency serial EIT system", Physiol. Meas, 17, pp.A7A13 (1996)

(22) X. Zhao, Y. Kinouchi, T. Iritani, T. Morimoto, and M. Takeuchi: "Estimation of Multi-Layer Tissue Conductivities from Non-invasively Measured Bioresistances Using Divided Electrodes", IEICE TRANS. INF. \& SYST., Vol.E85-D, No.6, pp.1031-1038 (2002)

(23) Xueli Zhao, Y. Kinouchi, E. Yasuno, D. Gao, T. Iritani, T. Morimoto, and M. Takeuchi: "A New Method for Noninvasive Measurement of Multilayer Tissue Conductivity and Structure Using Divided Electrodes", IEEE Trans. Biomed. Eng., Vol.51, No.2, pp.362-370 (2004)

（24）金井 寛: 「電磁気計測」,臨床検査，Vol.33, No.1, pp.88-94 (19891)

(25) K.R. Foster and H.P. Schwan: "Dielectrical properties of tissues and biological materials: a critical review", Critical Reviews in Biomedical Engineering, 17, pp.25-104 (1989)

(26) D.W. Davidson and R.H. Cole: "Dielectric relaxation in glycerol, propylene glycol, and n-propanol", J. Chem. Phys., 19, pp.1484-1490 (1951)

(27) 高橋 茂:「電気䋓縁材料の誘電特性並びに光の測定法の研究」, 電 気試験所研究報告, p.539 (1953)

(28) E. Yasuno, R. Kojima, Y. Tanji, Y. Kinouchi, and T. Morimoto: "Estimation of space distribution for the subcutaneous local tissue impedance.", IEICE Japan, Vol.100, No.190 (MBE2000-44), pp.39-46 (2000-7) (in Japanese) 安野恵実子·巟島理介·丹治佑介·木内陽介·森本忠興: 「局所皮下組織 インピーダンスの空間分布推定」, 信学技報 , 100 , 190 (MBE200044) , pp.39-46 (2000-7)

(29) E. Yasuno, R. Kojima, Y. Kinouchi, and T. Morimoto: "Estimation of Impedance Distribution in the Local Tissue Using a Divided Electrode - a New Method for the Impedance CT", Proc. of World Congress on Medical Physics and Biomedical Engineering, TH-FXH-01 (2000)

(30) E. Yasuno, Y. Kinouchi, T. Morimoto, and Y. Ohmine: "Estimation of space distribution for the local tissue impedance by using a divided electrode method", IEE Japan, IM-04-39, pp.23-28 (2004-10) (in Japanese)

安野恵実子 $\cdot$ 木内陽介・森本忠興・大嶺裕賢 $:\ulcorner$ 分割電極法による局 所組織インピーダンスの空間分布推定」, 電学計測研資, IM-04-39, pp.23-28 (2004-10) 
安 野 恵実子 (正員) 1997 年德島大学大学院工学研究科博士

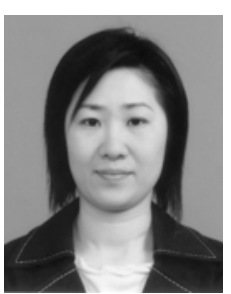
前期課程 (電気電子工学専攻) 修了。同年四国計 測工業 (株) 高松技術研究所入社。在職中は生体 インピーダンス計測装置の開発に従事。1999 年 1 月阿南工業高等専門学校制御情報工学科助手。 現在に至る。主として生体インピーダンスに関す る研究に従事。電子情報通信学会会員。

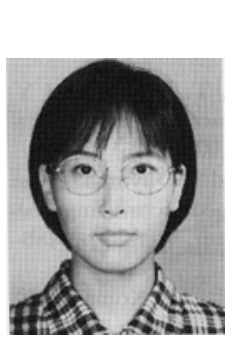

木 内 陽 介 (正員) 1968 年德島大学大学院工学研究科修士課 程 (電気工学専攻) 修了。同年同大助手。現在 , 同 工・電気電子工学科教授。医用生体工学に関する 研究に従事。工博。電子情報通信学会, 日本 $M E$ 学会, 計測自動制御学会, IEEE,BEMS 各会員。

森 本 忠 興 (非会員) 1967 年徳島大学医学部医学科卒業。 1977 年同大医学部助手。現在, 同大医学部保健 学科教授。医学博士。主として生体の電気特性に 関する研究に従事。日本乳癌学会, 日本乳癌検診 学会, 日本がん検診・診断学会, 日本臨床外科学 会, 日本 $M E$ 学会, 日本外科学会各会員。 